\title{
Legal Testing on Hate Speech Through Social Media
}

\author{
$1^{\text {st }}$ Erni Dwita Silambi \\ Law of Science Department, \\ Faculty of Law \\ Universitas Musamus \\ Merauke, Indonesia \\ erni@unmus.ac.id \\ $4^{\text {th }}$ Dina Fitri Septarini \\ Accounting Department, Faculty of \\ Economy and Business, \\ Universitas Musamus \\ Merauke, Indonesia \\ dina@unmus.ac.id
}

\author{
$2^{\text {nd }}$ Yuldiana Zesa Azis \\ Law of Science Department, \\ Faculty of Law \\ Universitas Musamus \\ Merauke, Indonesia \\ shesaazis@yahoo.com
}

\author{
$3^{\text {rd }}$ Marlyn Jane Alputila \\ Law of Science Department, \\ Faculty of Law \\ Universitas Musamus \\ Merauke, Indonesia \\ marlynjane16@gmail.com
}

\begin{abstract}
The rapid growth of technology, including in the internet, has led to an increase in crime. This study aims to find out the laws carried out by the police at Merauke Regional Police in enforcing Hate Speech Crime on social media 2. To find out the inhibiting factors in enforcing Hate Speech on social media. This research was conducted in Merauke Regency, Papua Indonesia in 2018. This research method is conducted using qualitative methods that collect by conducting interviews and literature studies. This study shows that: 1. Repetition and handling of hate speech The police conduct prevention and action. Repressive 2 . The factors that hinder this case are due to investigators, facilities and infrastructures and the absence of a special team that handles the case)
\end{abstract}

Keywords - enforcement, hate speech, media social

\section{INTRODUCTION}

The rapid development of technology has a huge impact on society both negative and positive influences and this happens not only for adults but also for children and adolescents. A very fast development in the field of technology is the availability of internet which is not only a trendy media but also an important requirement in human life. The internet is used to support work and can also be used as a source of income. One of the effects of the Internet is the use of media social.

Patrick Mauder in a study The results showed that the presence of social media companies on LinkedIn had a significant influence on the company's stock returns, while the presence of social media on Facebook and Twitter did not provide statistically significant results. Interestingly, this study also found that there was a difference between $\mathrm{B} 2 \mathrm{~B}$ and $\mathrm{B} 2 \mathrm{C}$ companies, which confirmed the significant impact between B2C companies on LinkedIn and stock returns. This finding is useful for company managers and social media activists who try to understand the impact of social media finance on company value [1].

Social media is a site that provides a place for users to interact online. Social media makes it easy for users to interact with one another, and instead can establish business relationships with people from various backgrounds. In this day and age social media has become a basic need for some people, they are like addicted people who will find it strange if one day not to use this information sharing site.

Nowadays social media has a lot of types, even because so much will make its users confused in choosing what social media is suitable for them. But basically social media only has one function, namely to establish communication online. As internet and mobile phone technology progress, social media also grows rapidly. Now to access Facebook, Whatsapp, Instagram or Twitter for example, it can be done anywhere and anytime just by using a mobile phone, social media is easily accessible to its users resulting in very high development which is not only developed in developed countries but also in developing countries including in Indonesia.

The use of social media for contemporary knowledge management is growing. Success stories range from the fields of marketing to emergency disaster management. However its 
application to improve public safety remains elusive. This article outlines a case study of the presence of outlaw motorcycle clubs on Twitter and explores several collection and analysis techniques that can be applied to generate insights for social media intelligence [2].

Because people who are so involved in social media that this is no longer a new thing, even social media is easily accessible to minors. The rapid development of social media because this media is so easily accessible and also the media that does not really need energy and time because peoplel does other work, we can access social media and also social media is considered a medium that is so cheap and does not require large capital. A social media user can access using social media with an internet network even though the access is slow, without large costs, without expensive tools and done alone without employees. We as social media users can freely edit, add, modify both writing, images, videos, graphics, and various other content models and then can be redistributed.

There has been little empirical research and theory development around how small to medium (SME) sized nonprofits are using social media, or how they are attempting to manage the risks associated with social media use, especially in the area of social media policy development [3].

The most prominent advantage of social media itself is that if we have opinions or writings there is no need to bother being published in newspapers or magazines so that people can see them. because social media accommodates this. So often we often find various types of personal opinion posts that get a lot of likes and even become viral in social media.

But on the other hand, this excess is sometimes misused by social media users, especially to overthrow others, spread false news and slander. The causes also vary from political interests, business competition, hatred towards a group and even those who just want to find a sensation.

Social media as a medium that is so easy to find and often provides news that is not necessarily true spread on social media coupled with the many habits of people who read the news and receive news that goes raw without being tested in advance. So it is not impossible that the spread of false news on social media quickly spread. Community culture that only reads without seeking the truth makes news that is not true so quickly spread. Merauke Regency is a district whose population is a population in which there are various tribes, religions, races and cultures.

The Merauke community, although already a modern society, is still very thick with customs and sometimes still prioritizes customary settlement rather than positive [4]

Crime cases that violate the ITE Law from 2011 to 2018 have occurred 27 cases of Crimes that occurred in Merauke Regency. Based on the above background, the author wants to study and examine further academically in a legal research entitled "Legal Testing Against Hate Speech Crimes Through Media.

Formulation of the problem

Based on the background of the above problems, the following problems can be formulated:

1. What is the legal effort made by the Merauke Regional Police in enforcing Hate Speech Crime on social media?

2. What is the inhibiting factor in the enforcement of Hate Speech Crimes on social media?.

\section{RESEARCH METHOD}

The method used in this legal research is an empirical juridical legal research method is a research method that serves to be able to see the law in two meaning yank from the law and examine how the law works in the community. Because of this empirical juridical legal research is to examine people in the relationship of life in society. Because this legal research is taken from the facts that exist in a community, legal entity or government agency and the relevant law. As well as this study uses a qualitative approach, that what you want to get and study by a study qualitative is thinking, meaning, human perspective about the symptoms that become the focus of the research. The meaning of thought and so on is an idea not a symptom

\section{RESULTS AND DISCUSSION}

In Indonesia, recent events have shown the terrible impact of the spread of hate messages, for example in the Tanjung Balai riots. The incident that occurred in July 2016 originated from a misunderstanding of some people, which was then uploaded and disseminated through social media. The person who receives the message without understanding the real problem then ignites anger, and contributes to the message [5]. In most cases in Africa, sexist hate speech will be used as a weapon of gender-based violence means to bully women into silence and to maintain men's privileges. By using Content Analysis and Critical Discourse Analysis approaches, this study analyzed the linguistic clues of the sexist hate speech in Facebook and Instagram social networks. On the basis of selected open accounts of Tanzanian public figures and celebrities, this study particularly observed and interrogated on how language of the users embeds ideological and social construct in order to perpetuate and exacerbate gender inequality. The study partly examined sexist hate speech in the selected Russian social media to comparatively study how sexism is construed and perceived in the community [6].

In the era of information disclosure and freedom of speech seemed to be a double-edged sword. On one side it is advantageous but on the other side it could be detrimental. Using the concept of pataphysics, this research tries to see how the Indonesian people are challenged to face the "flood of information" in social media and against the hoax, hate speech and social media abuse. Pataphysics tends to eliminate existing ones and hold ones that do not exist. The growing virtual era makes the dominance of physical and metaphysical power replaced by the power of image (pataphysics). The image that 
was originally the medium for message delivery, now becomes the message itself. Pataphysics in social media in recent days drove netizens familiar with the most recent Pataphysics products such as hoax, hate speech and social media abuse [7]

\section{1) The legal effort made by the Merauke Regional Police} in enforcing Hate Speech Crime on social media

The Republic of Indonesia Police as one of the state instruments in guarding the situation of security and order so that it remains conducive, the National Police also has a strategic role and is very important in handling Hate Speech. In line with the roles, functions and authorities mandated by the National Police, it requires the handling of Hate Speeches. So that crime acts in the form of Hate Speech can be reduced.

Data on the crime of the ITE Law in Merauke Regency which produced 3 (three) years in 2015 there were 2 cases, in 2016 there were 6 cases of 13 and 2017, while for cases of hate using social media namely Facebook since three years there were only 6 cases.

Table 1. the crime case of the ITE Law in the last three years

\begin{tabular}{|c|c|c|c|}
\hline \multirow{2}{*}{ No } & $\mathbf{3}$ & \multicolumn{3}{|c|}{ Number of cases } \\
\cline { 2 - 4 } & 2015 & $\mathbf{2 0 1 6}$ & $\mathbf{2 0 1 7}$ \\
\hline 1 & 2 & 13 & 6 \\
\hline
\end{tabular}

In 2016 there was a very significant increase, but in 2017 it experienced a decline and most cases only reached the level of investigation.

Table 2. The crime case of the ITE Law in the last three years

\begin{tabular}{|c|c|c|c|}
\hline \multirow{2}{*}{ No } & \multicolumn{3}{|c|}{ Number of cases } \\
\cline { 2 - 4 } & 2015 & 2016 & 2017 \\
\hline 1 & 2 & 2 & 3 \\
\hline
\end{tabular}

Data Polres Meraukje

Figure Labels: The results of the author's interview with BRIPKA, Rudi Satriadi, Investigator of the Economic Unit of the Merauke District Police's Criminal Investigation Unit, (Interview, 21 March 2018) stated that not many cases of hate speech reported in the three years from the case only reached the investigation stage.

Merauke Police Detective investigator said that Hate Speech Crime using social media Facebook accounts entered in Merauke Regional Police, but the case only arrived at the investigation stage and was stopped (report revocation) because there was a peace process between the reporting party and the reported party. (Interview March 21 2018)

Police officers at Merauke Regional police station have not been active in addressing cases of hate speech on social media. There are still a number of Facebook accounts that are still active and posting writings that are alleged to be expressions of hate but are not acted firmly because of the lack of evidence and also do not have adequate facilities and infrastructure.

Police efforts in tackling hate crimes (Hate Speech) include Non-Penal Efforts (Preventive \& Pre-Emictive) and Penal
(Repressive) Efforts. But what is prioritized in the settlement and overcoming of this hate speech crime is its preventive and pre-emptive efforts, because the criminal law (repressive) effort is the last resort that is used if the preventive method does not work.

\section{2) Inhibiting Factors in Enforcing Hate Speech Crimes in} Social Media

From the data the results of the research that the author got in the field, even though there was already a law but there were case reports that entered the Merauke Police Precinct Unit, there were still obstacles in the investigation process. It was said by BRIGPOL Apriandi Pasaribu, Merauke Police Unit Economic Unit Criminal Function (Interview, 11 April 2018) that the factors that hamper the investigators in carrying out their duties to investigate cases involving the ITE Law Crimes are:

1) Not yet established the National Police Cyber Team specifically handling Crimes that violate the ITE Law;

2) Lack of evidence;

3) Because in the process of investigation, special experts in the field of Telecommunications are required from the Ministry of Information and Communication, special experts in Criminal Law, and special experts in the Language taken from the outside so that it requires a fee; These things are constraints so that in handling each case it is hampered.

According to BRIPKA, Rudi Satriadi, the Investigator of the Economic Unit of Merauke District Police's Crime Unit, (Interview, March 21, 2018) There were 1 cases that had reached the stage of sending files to the Prosecutor's Office but were returned to the investigators because they were deemed insufficient and given instructions by prosecutors to be completed. This is why the case cannot arrive at the Judgment stage in the Court.

\section{CONCLUSION}

1. Law enforcement efforts against hate speech cannot be implemented optimally because of the lack of facilities and infrastructure owned by Merauke police station and the lack of evidence that can be used to ensnare perpetrators.

2. Factors inhibiting police efforts in tackling hate crimes (Hate Speech) are Internal Factors originating from the Merauke Police Investigators themselves. In terms of the ability of Merauke Police Investigation Members, they have not mastered and understood the case of hate speech on social media. In terms of facilities and equipment in carrying out the investigation, it is necessary to support adequate equipment according to the needs, but from the results of the research, there is no means of communication tools that are appropriate for carrying out the investigation task. Other facilities and facilities that are needed are the formation of a special team that is only responsible for taking action on cases that occur on social media such as the Cyber Team. 


\section{ACKNOWLEDGMENT}

Were conveyed to the Chancellor of Musamus University and Chairperson of the Musamus University Research and Community Service Institute (LPPM Unmus) who has assisted in the process of research activities so that research can be completed. The results of this study can finally be published in this article. In addition, the authors would like to thank all individuals and groups who contributed to the writing of this article even though they did not write.

\section{REFERENCES}

[1] P. Mauder, "The impact of social media followers on corporate value : An investigation of Australian firms," vol. 7, no. 1, pp. 1-12, 2018.

[2] N. Antonius, "Discovering collection and analysis techniques for social media to improve public safety," vol. 3, no. 1, pp. 42-53.

[3] S. J. Wilde, "Social Media in Micro and Small Third Sector Firms," Int. Technol. Manag. Rev., vol. 5, no. 3, pp. 135-141, 2015.

[4] E. D. Silambi, M. Jane, E. B. Rahail, D. Fitri, and S. Syahruddin, "Implementation of Customary Law in Merauke," vol. 46, no. 135, 2018.

[5] E. Santoso, "Pengendalian Pesan Kebencian (Hate Speech) Di Media Baru Melalui Peningkatan Literasi Media," Pros. Komun., pp. 154 164, 2016.

[6] S. Elias, "Relocating Gender Stereotypes Online: Critical Analysis of Sexist Hate Speech in Selected Social Media," vol. 228, no. Klua, pp. 272-277, 2018.

[7] Sirajuddin, S. U. R. Kamil, and S. Fachruddin, "War 3.0: The Indonesia Challenge Against Hoax, Hate Speech and Social Media Abuse," Adv. Soc. Sci. Educ. Humanit. Res., vol. 143, no. UICoSP, pp. 88-90, 2017. 